RPA Journals

\section{IJEKM}

International Journal of Education and Knowledge Management (IJEKM) Journal Homepage: https://rpajournals.com/ijekm

\title{
Global Warming: A Study on the Determination of Global Social Responsibility Levels of Final Year Students in Faculties of Medicine in Turkey
}

\author{
Cemil Orgev ${ }^{1}$ \\ Halil Demir $^{2 *}$ \\ Sakarya Applied Sciences University, Turkey' \\ Istanbul Rumeli University, Turkey ${ }^{2}$
}

\begin{abstract}
This study consists of two sections. In the first section, through a literature review, the impact of global warming on environmental factors such as winds, storms, hurricanes were investigated. Global warming and its possible consequences rise of the sea or ocean levels, number of hurricanes, their continuity, height and cost of damage in the next 50 years were assessed through a literature review. Additionally, it was discovered through the literature review that senior medical students' sensitivity to global warming and consequently to environmental health - had not been researched. In the second part of the study, the "Global Social Responsibility Scale" was administered to 431 final-year students studying at the faculties of medicine of Çapa, Cerrahpaşa, Hacettepe and Sakarya Universities. Environmental sensitivity of the students was investigated. It was found that the vast majority of the students $(76.57 \%)$ had not received any training on global warming until the time of the study. It was also found that the students receiving training had higher levels of awareness of global warming social responsibility. It is obvious that the adversities that will emerge due to global warming will negatively impact the lives of all living things. It is recommended to increase the level of "global social responsibility awareness" in terms of taking measures to stop the progress in this direction, protecting the habitats of living things on earth and ensuring the continuity of life.
\end{abstract}

Keywords: Global Warming, Environmental Pollution, Social Responsibility, Students of Medicine Faculty

*Corresponding author: Halil Demir; Email: halil.demir@ rumeli.edu.tr DOI: https://doi.org/10.37227/IJEKM-2020-02-22/

\section{Introduction}

"Global warming" is a term used to describe the increase in the average temperatures of the atmosphere - covering our world like a thin membrane and being the foundation of life - and of the waters in the oceans of the world forming two thirds of the planet we live in; it poses a serious threat to the world. The increase in the amount of gases (such as carbon dioxide, methane, nitrous oxide, carbon monoxide, chlorofluorocarbon (CFC)) that cause the natural greenhouse effect to be increased due to the rapid industrialization based on the industrial revolution causes the natural balance to deteriorate, increasing the temperature over time (Nart, 2009; Spence, 2007; Uzmen, 2007; Çepel, 2008). It is 
the greatest environmental problem that has been discussed in the 21 st century, which emerged due to human intervention (in scientific, political, economic and ethical fields) (Schreiner et al., 2005). It is a concept that makes its presence felt from the deepest depths of the oceans to the highest peaks of the Earth, and from the equator to the poles, necessitating a multi-dimensional handling of the subject (Kaya, 2013).

Instrumental measurements since 1860 have shown that the average temperature on the Earth's surface has increased noticeably, especially since the 1970s, and that the world's climate has entered not a cold period, but rather into a dangerously hot period (Uzmen, 2007; Orbay et al., 2009). The increase in greenhouse gas accumulations and particles in the atmosphere caused by mankind causes damage to the natural environment, the thinning of the ozone layer, and a rise in temperatures in the global dimension (Öztürk, 2002).

The climate's being in a constant warming process, the greenhouse gas (GHG) and aerosols partly caused by human activities - including emissions - and the changes in land use worsens the characteristics of tropical cyclones (Anthes, et al., 2006). Storm fluctuations atmospherically force the oscillation of water levels of coastal or inland water masses, and fluctuations are, in fact, generated through the atmospheric pressure that drops after causing a minimal increase in the water level through wind stresses (Karim and Mimura 2008). A definite and valid outcome has not been reached on whether global warming had a direct effect on winds, although it has been studied from different perspectives and it has been subject to many studies. However, just like Anthes et al., have stated in their study titled "Hurricanes and global warming - Potential linkages and consequences," the increase in the number of hurricanes and the rises in sea levels are ignored by saying that global warming is not directly related to winds (Anthes et al., 2006).

Algae are "cyanobacteria known as prokaryotic organisms and blue-green algae," and eukaryotic organisms, which are also photosynthetic. Just like plants, algae also feed on sunlight and play a significant role in a number of ecosystems. They offer food and shelter to several different types of aquatic animals. Although algae bloom usually takes place naturally, some is due to human activity, even though partly. Two of these factors are the nutritional loading and the climate change (Bennett 2017). Climatic changes can also cause drought, and thus, salinization occurs in freshwater environments. While this causes sea algae to invade such environments, it also causes water pollution and fish deaths.

From the 1950s onwards, awareness-raising efforts for the prevention of air, water, soil, noise and visual pollution have begun, after realizing that they had resulted from the over-production and consumption activities of human beings - examples of the efforts include First World Climate Conference under the leadership of World Meteorological Organization (1979) and the Second World Climate Conference (1990) again under the leadership of the World Meteorological Organization; Montreal Protocol (1987); The Changing Atmosphere Toronto Conference (1988); United Nations Climate Change and Environment Conference (1992); Kyoto Protocol (1997); Bali Climate Change Conference (2007); Ponzan Climate Conference (2008); and Copenhagen Climate Summit (2009) (Akın 2006). The studies that have been conducted also demonstrate the importance of the societal conscious in global warming, in the process of taking measures. In this study, it was foreseen - based on the literature reviews and evaluations carried out in the first stage - that hurricanes and floods will rise between $0.3 \mathrm{~m}$ and $0.8 \mathrm{~m}$ in the next 50 years. In the second stage, it was seen through the literature review that there were no 
literature studies and evaluations about the "Global Social Responsibility" levels of medical students at their final years. To that end, the "Global Social Responsibility Scale" questionnaire was administered to senior students of the Faculty of Medicine in three different universities to determine their sensitivity to the environment. Recommendations were made as a contribution to the literature in order to increase sensitivity levels according to the results obtained by analyses and assessments.

\section{Material and Method}

The study consisted of two sections. In the first section, the concept of global warming and its effects on environmental factors such as storms and algae were investigated. The "Global Social Responsibility" questionnaire was administered to a total of 431 students who studied in Hacettepe Faculty of Medicine in Ankara, Sakarya Faculty of Medicine in Sakarya, Cerrahpaşa and Çapa Faculties of Medicine in Istanbul.

\section{Research Method and Measurement Instrument}

The effects of global warming on ocean waves and algae were investigated through a literature review in the first part of the study. The "Global Social responsibility" scale constituted the second part of the study. Permission to use the scale was taken on December 04, 2017, by contacting Enis Harun Başer, and this questionnaire was used as a measurement instrument. The questionnaire, which was administered to participants through the random sampling method, consisted of two parts including the section through which the demographic information was collected. In the first part of the questionnaire, the gender of the respondents, the educational status of their parents, and whether the respondents received any training on global warming were investigated. In this part, 30 expressions about global warming were used to collect students' responses. The expressions were each in the form of a 5-point Likert scale where $1=$ strongly disagree, 2 $=$ disagree, $3=$ undecided, $4=$ agree and $5=$ strongly agree (Başer and Kılınç 2015). The permission to use "The social responsibility scale" which includes the second part of study was taken from Enis Harun Başer on December 4, 2018. 2.2.

\section{Research Population and Sample}

The research population of this study consisted of a total of 4544 students studying in Hacettepe Faculty of Medicine in Ankara $(n=1487)$, Sakarya Faculty of Medicine in Sakarya $(n=589)$, and Cerrahpaşa and Çapa Faculties of Medicine in Istanbul $(n=2468)$ between 2017 and 2018. In the study, it was determined that 354 students had to be included in the study in order to represent the research population at $\mathrm{p}=0.5$ significance and 95\% confidence level (Coşkun, et al., 2017). The questionnaire forms were distributed to 450 students as a sample. Due to incomplete and insufficient information, only 431 questionnaire forms were found to be eligible for evaluation. 


\section{Findings}

The findings of our study consisted of the results of the literature review and the results of the questionnaire carried out to determine the "Global Social Responsibility" levels of the medical students.

\section{Findings from the Literature}

In this part of our study, the research studies with different perspectives were examined, which were about the effects of global warming on storms and algae.

\section{The Effect of Global Warming on Storms (Hurricanes)}

McCarthy et al., (2001) have reported that local changes at sea levels could be much more than average global changes due to land subsidence and changes in large-scale oceanic and atmospheric circulations. As a result of their study, Barnet et al., (2005) have found that the changes observed in the tropical oceans in recent years and the corresponding changes in atmospheric and oceanic circulations include a human-based component. Anthes et al., (2006) have stated that the subject is not black or white. Instead, they have stated that global warming - although not yet fully understood - has a widespread effect on oceanic temperature and heat content of oceans, atmospheric temperature, water vapor, and atmospheric and oceanic general circulation models.

Potential relationships between tropical cyclones and the global climate change are scientifically and socially complex. What is exceptional about the nature of the 2005 North Atlantic hurricane season is that it alone offers great opportunities to better understand the interactions and the causes and effects of these interactions. Having the largest number of storms with continuous winds over $17 \mathrm{~ms}-1$ (Orr et al. 2005) and having the largest hurricane with continuous winds over 33 ms-1 (Başer and Kılınç, 2015), the 2005 season was declared the only year that had 5 storms in three categories with a maximum continuous wind over $67 \mathrm{~ms}-1$. In the records, Wilma was recorded as the most intense storm (minimum pressure $882 \mathrm{hPa}$ ), Rita as the heaviest storm in the Gulf of Mexico $(897 \mathrm{hPa})$ and Katrina as the storm with the highest cost ( $\$ 200$ billion on some estimates) (Anthes, 2006).

Smith (2009) has stated that hurricanes shape the structure of the mangrove forests in the Everglades through wind damage, storm fluctuations and sediment accumulation. He reported that the long-term effects of hurricanes on mangroves are not yet sufficiently understood and that fluctuations along Wilma have destroyed mangroves in about 1,250 ha area. He also stated that there was no difference between the Andrew and Wilma hurricanes in terms of \% trunk death rate or \% basal area loss based on the data from permanent lands affected by the hurricanes.

Wind-induced surface waves are seen not only as an important modulator in air-sea exchange (Cavaleri et al., 2012; Fan and Griffies, 2014; Breivik et al., 2015) but also an important variable in climate forecasts such as coastal erosion, flooding, and offshore and sea transportation designs, contributing to offshore and coastal security (Hemer et al., 2012). However, unified climatic models, other than a few exceptions (Fan and Griffies 2014; Li et al., 2016), are yet to include wave models (Li et al., 2016). 
The results of hydrodynamic simulations show that rises in hurricane floods will intensify and floods will rise approximately 0.3 and $0.8 \mathrm{~m}$ in the $2030 \mathrm{~s}$ and $2080 \mathrm{~s}$, respectively, if future global warming projections take place. It has been reported that global warming, and consequently, increased water levels, as well as hurricanes that take place will lead to more widespread flooding and damage, and that such incidents will bring about comprehensive regional and national economic consequences (Mousavi et al., 2011).

\section{The Effect of Global Warming on The Algae Ecosystem and Acidification of Ocean Water}

The global data that is being gathered show that oceans absorb at least half of $\mathrm{CO}_{2}$ emissions originating from human activities since 1750 (Sabine, et al., 2004). When dissolved in water, the $\mathrm{CO}_{2}$ in the atmosphere decomposes to carbonic acid $\left(\mathrm{H}_{2} \mathrm{CO}_{3}\right)$, and carbonic acid decomposes to carbonate $\left(\mathrm{CO}_{3.2}\right)$ and hydrogen $\left(\mathrm{H}^{+}\right)$ions and causes ocean surface waters to be $30 \%$ more acidic on average (Doney, 2006). Because certain marine organisms, such as mollusks, crustaceans, corals reefs, and certain algae and phytoplankton species, are particularly vulnerable to minor changes in $\mathrm{pH}$ levels, the immense amount of increase in the ocean acidity affects them seriously. All of these species, known as "seashells," form skeletons or shells made from calcium carbonate. If the carbonate ion, which is the basic building block in this process, is combined with the hydrogen ions released by the carbonic acid, it becomes useless for the shell-forming organisms and the calcium carbonate shells are dissolved as the acidity of the seawater increases. For this reason, due to increased atmospheric carbon dioxide levels in this century, the concentration of carbonate ions is expected to decrease by half (Orr et al., 2005).

Cyanobacterial bloom (the rapid proliferation of blue-green algae) leads to several negative effects, and hypoxia and anoxia are two of the most harmful consequences. When dissolved oxygen levels in water is low, it is called hypoxia. When the state of dissolved oxygen levels in the water is extremely low or near zero, it is called anoxia. When they occur in enclosed coastal environments, these algae blooms cause regional anoxia, fish deaths, and death of other marine creatures (O'neil et al., 2012). When cyanobacteria begin to die, they cause oxygen depletion because of microbial degradation of cyanobacterial cells, risking aquatic flora and fauna (Nakano et al., 2016).

\section{Findings of the Global Social Responsibility Questionnaire}

Blum, (1985) who has developed an environmental approach to the concept of health, has stated that four fundamental factors such as environment, behavior (lifestyle), health care services and heredity (genetic structure) affect the status of health, and that these factors cause various effects and damages on the body and systems of human beings (Schultz and Johnson 1976). Although the level of influence of these four factors varies, the most important factor among them is the environment, followed by the lifestyle, personal behavior, heredity and health care services factors. As human beings always reside in the external environment, it is inevitable that they are influenced by the environment because of their biological and psychological structures. The environment, at the same time, is the system of supplying and maintaining life. It is from this context that this study was carried out on the medical students in order to investigate the sensitivity of the future physicians to environmental problems and to raise awareness, if necessary, in terms of "environmental health" and, especially, "global warming" that will affect human health, due to their direct relationship with human health. 


\section{Reliability and Validity of The Scale}

In order to calculate the reliability of the questionnaire developed for the "Global Social Responsibility" scale, the Cronbach alpha coefficient was used. Based on the analysis, the Cronbach alpha coefficient was calculated as .751, which is high and acceptable. The Kaiser-Meyer-Olkin (KMO) value was found to be .855; that is, it was greater than 60 . And, the Bartlett Sphericity test was found to be significant (X2=3492.388; $\mathrm{p}=.00)$.

\section{Demographic Findings}

The SPSS 20 package program was used to analyze the data. First, the demographic characteristics of the senior students who participated in the questionnaire were organized as frequency tables and given in Table 1.

Table 1. Students' Genders and Their Parents' Educational Levels
\begin{tabular}{|l|l|l|}
\hline Gender & Frequency & $\%$ \\
\hline Male & 183 & 42.5 \\
\hline Female & 248 & 57.5 \\
\hline Total & $\mathbf{4 3 1}$ & $\mathbf{1 0 0}$ \\
\hline Parental educational status & Frequency & $\%$ \\
\hline Father - Elementary School & 145 & 33.6 \\
\hline Father - High School & 117 & 27.1 \\
\hline Father - Bachelor's Degree & 109 & 25.3 \\
\hline Father - Master's Degree & 42 & 9.7 \\
\hline Father - Doctoral Degree & 18 & 4.2 \\
\hline Total & $\mathbf{4 3 1}$ & $\mathbf{1 0 0}$ \\
\hline Mother - Elementary School & 212 & 49.2 \\
\hline Mother - High School & 106 & 24.6 \\
\hline Mother - Bachelor's Degree & 75 & 17.4 \\
\hline Mother - Master's Degree & 31 & 7.2 \\
\hline Mother - Doctoral Degree & 7 & 1.6 \\
\hline Total & $\mathbf{4 3 1}$ & $\mathbf{1 0 0}$ \\
\hline
\end{tabular}

Only $12 \%$ of the 1895479 students taking the university entrance exam during the 20122013 periods in Turkey (OSYM 2013) were able to be accepted by medical schools (OSYM 2012). Nevertheless, a large majority of the 330 students (76.57\%) of those participating in the study, who would serve specifically in the human health sector in the future, had not taken any training on global warming until then.

\section{Results}

Based on this research study, which was carried out to raise global social awareness, a correlation matrix was formed to identify any potential relationship between the response variables. As a result of the matrix, the relationship between the response variables was found to be suitable for conducting a factor analysis. Table 2 shows the results of the $t-$ test carried out for the opinions of the students on global warming.

The opinions of the students about the questions $25,15,29,22,2,4$, and 23 had significantly positive trends, and the opinions about the questions 7, 11, 18, and 20 had significantly negative trends. However, the negative trends were actually found to be positive in the sense of being sensitive to the environment, originating from the way the questions were asked. 
In the factor analysis carried out on the data set, a varimax rotation was applied. Based on the analysis, 5 variables were found to have high eigen values. When the Scree Plot given in Figure 1 was examined, it was confirmed that it had a 5- factor structure. The number of factors was set to be 5 , and a new analysis was run.

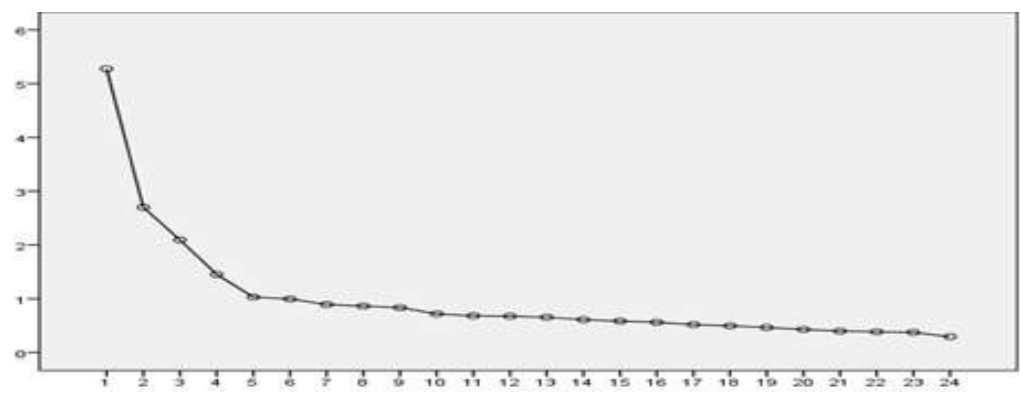

Number of Components

Figure 1: Scree Plot

Table 2. The One Sample T-Test

\begin{tabular}{|c|c|c|c|c|c|c|c|}
\hline & & & & \multicolumn{4}{|c|}{ Test value $=3$} \\
\hline & & & & & & $\begin{array}{r}95 \% \text { co } \\
\text { interva } \\
\text { diffe }\end{array}$ & $\begin{array}{l}\text { idence } \\
\text { of the } \\
\text { nce }\end{array}$ \\
\hline & Mean & $\mathrm{T}$ & Df & $\begin{array}{c}\text { Sig. } \\
\text { (2taile } \\
\text { d) }\end{array}$ & $\begin{array}{l}\text { Mean } \\
\text { difference }\end{array}$ & Lower & Upper \\
\hline 25.It must be mandatory to recycle newspapers, bottles, cans and similar materials. & 4.4037 & 32.039 & 430 & 0 & 1.40371 & 1.3176 & 1.4898 \\
\hline 15.I behave with the understanding that people have to protect the environment where they live. & 4.2761 & 28.948 & 430 & 0 & 1.2761 & 1.1895 & 1.3627 \\
\hline 29.I look after other people's rights. & 4.0835 & 24.153 & 430 & 0 & 1.08353 & 0.9954 & 1.1717 \\
\hline 22.All the individuals in the world are valuable to me. & 3.9977 & 19.875 & 430 & 0 & 0.99768 & 0.899 & 1.0963 \\
\hline 2. I think there are useful things that I can do to protect the environment. & 3.9907 & 20.665 & 430 & 0 & 0.99072 & 0.8965 & 1.0849 \\
\hline 4.I care about the prosperity of other people. & 3.9814 & 20.769 & 430 & 0 & 0.98144 & 0.8886 & 1.0743 \\
\hline 23.I am willing to help for poor people in under developed countries. & 3.9582 & 21.526 & 430 & 0 & 0.95824 & 0.8707 & 1.0457 \\
\hline 28.I support social responsibility projects for countries suffering from food shortages in the world. & 3.7865 & 18.408 & 430 & 0 & 0.78654 & 0.7026 & 0.8705 \\
\hline $\begin{array}{l}\text { 9.I contribute to the efforts to improve the awareness of the society against global environmental } \\
\text { problems. }\end{array}$ & 3.7564 & 16.942 & 430 & 0 & 0.75638 & 0.6686 & 0.8441 \\
\hline $\begin{array}{l}\text { 14.I support the activities of international organizations to solve environmental problems within } \\
\text { the bounds of possibility. }\end{array}$ & 3.7425 & 17.375 & 430 & 0 & 0.74246 & 0.6585 & 0.8264 \\
\hline 8.Our country should do what it can to solve the problems in neighboring countries. & 3.7239 & 13.638 & 430 & 0 & 0.7239 & 0.6196 & 0.8282 \\
\hline 30.I participate in the activities of organizations that are fighting against environmental pollution. & 3.6937 & 14.343 & 430 & 0 & 0.69374 & 0.5987 & 0.7888 \\
\hline 24.I support international relief efforts by purchasing products sold for help. & 3.6265 & 12.729 & 430 & 0 & 0.62645 & 0.5297 & 0.7232 \\
\hline $\begin{array}{l}\text { 12.I donate in order to support people in the world who experience difficulties in finding medical } \\
\text { products. }\end{array}$ & 3.5476 & 10.598 & 430 & 0 & 0.54756 & 0.446 & 0.6491 \\
\hline 5.I support the campaigns of international non-governmental organizations. & 3.5035 & 10.868 & 430 & 0 & 0.50348 & 0.4124 & 0.5945 \\
\hline 10.I make financial donations for areas in the world that are damaged by natural disasters. & 3.4803 & 9.053 & 430 & 0 & 0.48028 & 0.376 & 0.5845 \\
\hline 16.I encourage my acquaintances to participate in international voluntary activities. & 3.4432 & 8.853 & 430 & 0 & 0.44316 & 0.3448 & 0.5415 \\
\hline $\begin{array}{l}\text { 19.I play an active role in improving the sensitivity to global social problems of the society } \\
\text { (language,racism,andsoforth). }\end{array}$ & 3.3852 & 7.031 & 430 & 0 & 0.38515 & 0.2775 & 0.4928 \\
\hline 6.I encourage inparticipate in the activities of charitable organizations. & 3.3434 & 6.538 & 430 & 0 & 0.34339 & 0.2402 & 0.4466 \\
\hline 21.I would like the taxesi pay to bespent only form your own country/citizens. & 3.2599 & 4.19 & 430 & 0 & 0.25986 & 0.138 & 0.3818 \\
\hline $\begin{array}{l}\text { 13.The state should work harder in order to find solutions to the problems of migrants } \\
\text { (Syrians,and so forth). }\end{array}$ & 3.1879 & 3.085 & 430 & $\begin{array}{ll}0.0 \\
02\end{array}$ & 0.18794 & 0.0682 & 0.3077 \\
\hline 1.I play an active role in the creation of global social responsibility projects. & 3.1508 & 2.721 & 430 & $\begin{array}{ll}0.0 \\
07\end{array}$ & 0.15081 & 0.0419 & 0.2597 \\
\hline $\begin{array}{l}\text { 26.We have to deal with solving the problems in our own country instead of helping other } \\
\text { countries. }\end{array}$ & 3.1462 & 2.557 & 430 & $\begin{array}{c}0.0 \\
11\end{array}$ & 0.14617 & 0.0338 & 0.2585 \\
\hline $\begin{array}{l}\text { 27. Since there are many problems with regard to poor people in turkey, we should not spend } \\
\text { money on the problems of other countries. }\end{array}$ & 3.123 & 2.153 & 430 & $\begin{array}{l}0.0 \\
32\end{array}$ & 0.12297 & 0.0107 & 0.2352 \\
\hline 3. Individuals should work only to improve their own countries. & 2.1694 & 13.568 & 430 & 0 & 0.83063 & 0.951 & 0.7103 \\
\hline 17. There is nothing I can do to protect the endangered plant and animal species. & 2.0441 & 17.295 & 430 & 0 & 0.95592 & 1.0646 & 0.8473 \\
\hline 20. There striction of rights and freedoms in other countries is not important to me. & 1.8886 & 20.692 & 430 & 0 & 1.11137 & 1.2169 & 1.0058 \\
\hline 18.I do not care about the problems of people in other countries. & 1.877 & 21.964 & 430 & 0 & 1.12297 & 1.2235 & 1.0225 \\
\hline 11.It is not necessary for an individual to worry about other people. & 1.6102 & 28.571 & 430 & 0 & 1.38979 & 1.4854 & 1.2942 \\
\hline
\end{tabular}


When conducting a factor analysis, it is necessary to pay attention to whether variables can be fully loaded into the factor 4 loads and each factor. Although these values can be flexible depending on the data set, the factor load is expected to be around 45 and the difference between the factor loads of each variable is expected to be .1; otherwise, it can be said that the variable cannot sufficiently load the factor. In the factor analysis run on this data set, the minimum factor load was accepted to be 45 . However, in order to ensure these conditions, items $2,4,5,8,12$, and 24 were excluded from the scale, since the difference between the factor loads of these items was less than .1. As a result of this, the factors and the factor loads based on the analysis are given in Table 3.

Table 3. Factor Analysis Run on the Data Set

\begin{tabular}{|c|c|c|c|c|c|}
\hline & \multicolumn{5}{|c|}{ Factors } \\
\hline & 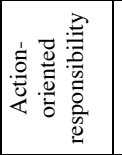 & 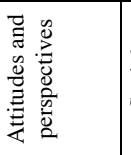 & 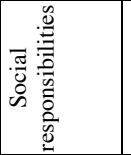 & 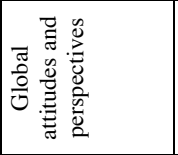 & 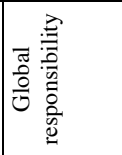 \\
\hline $\begin{array}{l}\text { 9.I contribute to the efforts to improve the awareness of the society against } \\
\text { global environmental problems. }\end{array}$ & .682 & & & & \\
\hline 1.I play an active role in the creation of global social responsibility projects. & .655 & & & & \\
\hline $\begin{array}{l}\text { 16.I encourage my acquaintances to participate in international voluntary } \\
\text { activities. }\end{array}$ & .651 & & & & \\
\hline $\begin{array}{l}\text { 6.I encourage my acquaintances to participate in the activities of charitable } \\
\text { organizations }\end{array}$ & .621 & & & & \\
\hline $\begin{array}{l}\text { 19. I play an active role in improving the sensitivity to the global social } \\
\text { problems of the society (language, racism and so forth). }\end{array}$ & .549 & & & & \\
\hline $\begin{array}{l}\text { 10. I make financial donations for areas in the world that are damaged by } \\
\text { natural disasters. }\end{array}$ & .548 & & & & \\
\hline 11. It is not necessary for an individual to worry about other people. & & .724 & & & \\
\hline $\begin{array}{l}\text { 7. It does not botherme that environmental pollution has been increasing in } \\
\text { the world. }\end{array}$ & & .666 & & & \\
\hline 18. I do not care about the problems of people in other countries. & & .631 & & & \\
\hline 3. Individuals should work only to improve their own countries. & & .589 & & & \\
\hline $\begin{array}{l}\text { 20. There striction of rights and freedoms in other countries is not important } \\
\text { to me. }\end{array}$ & & .559 & & & \\
\hline $\begin{array}{l}\text { 17. There is no thing I can do to protect the endangered plant and animal } \\
\text { species. }\end{array}$ & & .555 & & & \\
\hline 23. I am willing to help for poor people in under developed countries. & & & .653 & & \\
\hline 22. All the individuals in the world are valuable to me. & & & .635 & & \\
\hline 29. I look after other people's rights. & & & .615 & & \\
\hline $\begin{array}{l}\text { 15. I behave with the understanding that people have to protect the } \\
\text { environment where they live. }\end{array}$ & & & .605 & & \\
\hline $\begin{array}{l}\text { 25. It must be mandatory to recycle newspapers, bottles, cans and similar } \\
\text { materials. }\end{array}$ & & & .581 & & \\
\hline $\begin{array}{l}\text { 27. Since there are many problems with regard to poor people in turkey, we } \\
\text { should not spend money on the problems of other countries. }\end{array}$ & & & & .787 & \\
\hline $\begin{array}{l}\text { 26. We have to deal with solving the problems in our own country instead of } \\
\text { helping other countries. }\end{array}$ & & & & .778 & \\
\hline 21.I would like the taxesi pay to bespent only formy own country/citizens. & & & & .753 & \\
\hline $\begin{array}{l}\text { 13.The state should work harder in order to find solutions to the problems of } \\
\text { migrants (Syrians,and soforth). }\end{array}$ & & & & -.486 & \\
\hline $\begin{array}{l}\text { 28.I support social responsibility projects for countries suffering from food } \\
\text { shortages in the world. }\end{array}$ & & & & & .717 \\
\hline $\begin{array}{l}\text { 30. I participate in the activities of organizations that are fighting against } \\
\text { environmental pollution. }\end{array}$ & & & & & .604 \\
\hline $\begin{array}{l}\text { 14.I support the activities of international organizations to solve } \\
\text { environmental problems within the bounds of possibility. }\end{array}$ & & & & & .547 \\
\hline
\end{tabular}


Table 4 shows the variance and cumulative variance values explained by the factors, based on the factor analysis after the necessary modifications.

Table 4. Variance and Cumulative Variance Values Explained based on Factor Analysis

\begin{tabular}{|l|c|l|}
\hline \multicolumn{1}{|c|}{ Factors } & $\begin{array}{c}\text { Variance values } \\
\text { explained }\end{array}$ & $\begin{array}{l}\text { Cumulative variance } \\
\text { values explained }\end{array}$ \\
\hline Factor1 (Action-oriented responsibility) & 12.476 & 12.476 \\
\hline Factor2 (Attitudes and perspectives) & 11.755 & 24.231 \\
\hline Factor3 (Social responsibilities) & 11.184 & 35.415 \\
\hline Factor4 (Global attitudes and perspectives) & 9.805 & 45.220 \\
\hline Factor5 (Global responsibility) & 7.084 & 52.304 \\
\hline
\end{tabular}

Table 4 shows that the contributions of factors to the total variance explained $(52.303 \%)$ were found to be $12.476 \%, 11.755 \%, 11.184 \%, 9.805 \%$, and $7.084 \%$ for Factor 1, 2, 3, 4, and 5, respectively. It is considered sufficient to have a total variance explained value between $40 \%$ and $60 \%$. Therefore, it is seen that the total variance explained in this context was sufficient.

An ANOVA was run to find out whether there was a difference between university levels on the basis of factor variables. In this case, the hypotheses were created as follows:

$\mathrm{H}_{0}$ : There is no difference between mean scores.

$\mathrm{H}_{1}$ : There is a significant difference between at least two mean scores.

Table 5. ANOVA Results according to Universities

\begin{tabular}{|c|c|c|c|c|c|c|}
\hline & & Sum of squares & Df & Mean squares & $\mathrm{F}$ & $\mathrm{P}$ value \\
\hline \multirow{3}{*}{$\begin{array}{l}\text { Action-oriented } \\
\text { responsibility }\end{array}$} & Between groups & 13.605 & 2 & 6.803 & 6.992 & .001 \\
\hline & Within groups & 416.395 & 428 & .973 & & \\
\hline & Total & 430.000 & 430 & & & \\
\hline \multirow{3}{*}{ Attitudes and perspectives } & Between groups & 6.561 & 2 & 3.280 & 3.316 & .037 \\
\hline & Within groups & 423.439 & 428 & .989 & & \\
\hline & Total & 430.000 & 430 & & & \\
\hline \multirow{3}{*}{ Social responsibilities } & Between groups & 15.368 & 2 & 7.684 & 7.932 & .000 \\
\hline & Within groups & 414.632 & 428 & .969 & & \\
\hline & Total & 430.000 & 430 & & & \\
\hline \multirow{3}{*}{$\begin{array}{l}\text { Global attitudes and } \\
\text { perspectives }\end{array}$} & Between groups & 4.065 & 2 & 2.033 & 2.042 & .131 \\
\hline & Within groups & 425.935 & 428 & .995 & & \\
\hline & Total & 430.000 & 430 & & & \\
\hline \multirow{3}{*}{ Global responsibility } & Between groups & 5.528 & 2 & 2.764 & 2.787 & .063 \\
\hline & Within groups & 424.472 & 428 & .992 & & \\
\hline & Total & 430.000 & 430 & & & \\
\hline
\end{tabular}

According to Table 5, the hypothesis $\mathrm{H} 0$ was rejected because the $\mathrm{p}$ values of Factor 1 $(\mathrm{p}=.001)$, Factor $2(\mathrm{p}=.0037)$ and Factor $3(\mathrm{p}=.000)$ were less than .05 , which is the alpha value. There was a difference between the mean scores of university levels in terms of these three factors. According to Table 5, the hypothesis $\mathrm{H} 0$ was accepted because the $\mathrm{p}$ values of Factor $4(\mathrm{p}=.131)$ and Factor $5(\mathrm{p}=.063)$ were greater than .05 , which is the alpha value. There was no difference between the mean scores of university levels in terms of these two factors.

For factors with a significant difference between the mean scores of university levels, a Post-Hoc test was conducted to see which university created the difference. The results are given in Table 6 . 
Table 6. POST-HOC (Scheffe Test) Multiple Comparison Test Results

\begin{tabular}{|c|c|c|c|}
\hline Dependent variable & UNIVERSITY(I) & UNIVERSITY(J) & $\begin{array}{c}\text { Meandifference } \\
(\mathrm{I}-\mathrm{J})\end{array}$ \\
\hline \multirow{3}{*}{$\begin{array}{l}\text { Action-oriented } \\
\text { responsibility }\end{array}$} & \multirow[t]{2}{*}{ Sakarya University } & Hacettepe University & .17498525 \\
\hline & & Çapa Faculty of Medicine & -.26107898 \\
\hline & \multirow[t]{2}{*}{ Hacettepe University } & Sakarya University & -.17498525 \\
\hline \multirow{3}{*}{$\begin{array}{l}\text { Attitudes and } \\
\text { perspectives }\end{array}$} & & Çapa Faculty of Medicine & $-.43606423 *$ \\
\hline & \multirow{2}{*}{$\begin{array}{c}\text { Çapa Faculty of } \\
\text { Medicine }\end{array}$} & Sakarya University & .26107898 \\
\hline & & Hacettepe University & $.43606423 *$ \\
\hline \multirow{3}{*}{ Social responsibilities } & \multirow[t]{2}{*}{ Sakarya University } & Hacettepe University & -.27660483 \\
\hline & & Çapa Faculty of Medicine & -.23844421 \\
\hline & \multirow[t]{2}{*}{ Hacettepe University } & Sakarya University & .27660483 \\
\hline \multirow{3}{*}{$\begin{array}{l}\text { Action-oriented } \\
\text { responsibility }\end{array}$} & & Çapa Faculty of Medicine & .03816061 \\
\hline & \multirow{2}{*}{$\begin{array}{l}\text { Çapa Faculty of } \\
\text { Medicine }\end{array}$} & Sakarya University & .23844421 \\
\hline & & Hacettepe University & -.03816061 \\
\hline \multirow{6}{*}{$\begin{array}{l}\text { Attitudes and } \\
\text { perspectives }\end{array}$} & \multirow[t]{2}{*}{ Sakarya University } & Hacettepe University & $.28858540 *$ \\
\hline & & Çapa Faculty of Medicine & $.458815195 *$ \\
\hline & \multirow[t]{2}{*}{ Hacettepe University } & Sakarya University & $.28858540 *$ \\
\hline & & Çapa Faculty of Medicine & .17026655 \\
\hline & \multirow{2}{*}{$\begin{array}{c}\text { Çapa Faculty of } \\
\text { Medicine }\end{array}$} & Sakarya University & $.45885195 *$ \\
\hline & & Hacettepe University & -.17026655 \\
\hline
\end{tabular}

In Table 6, significant values under the mean difference column are marked with an asterisk. For Factor 1, the difference between Hacettepe University and Çapa Faculty of Medicine was found to be significant. For Factor 2, although a significant difference was found in the ANOVA table, there was no significant difference in the multiple comparison table. This was due to the fact that the sample size was not sufficient to prove it. For Factor 3, Sakarya University turned out to be different from Hacettepe University as well as Çapa Faculty of Medicine. The university that created the difference for this factor was Sakarya University.

Table 7 shows the results on whether the students had previously received any training on global warming.

Table 7. Comparison of Whether the Students Received Comprehensive Training on Global Warming

\begin{tabular}{|c|c|c|c|c|}
\hline \multirow{2}{*}{ Responses } & \multicolumn{4}{|c|}{ The Numbers and Percentages of Yes-No } \\
& Sakarya & Hacettepe & Çapa & Grand total \\
\cline { 2 - 5 } & $42(28.57 \%)$ & $33(22.45 \%)$ & $26(18.98 \%)$ & $101(23.43 \%)$ \\
\hline Yes (Percent) & $105(71.43 \%)$ & $114(77.55 \%)$ & $111(81.02 \%)$ & $330(76.57 \%)$ \\
\hline No (Percent) & 147 & 147 & 137 & 431 \\
\hline Grand total & \multicolumn{4}{|c}{} \\
\hline
\end{tabular}

A comparison of the medical students according to the universities as seen in Table 7 shows that Sakarya University had the highest rate of yes $(28.57 \%)$ in itself, while Hacettepe University had the highest rate of no $(81.02 \%)$ in itself.

\section{Discussion and Concluding Remarks}

In the literature review section of this study, it is stated that due to the global warming, $\mathrm{pH}$ has fallen in the sea water, and the sea water is transformed into an acidic structure. In addition, certain marine organisms such as mollusks, crustaceans, coral reefs and certain algae and phytoplankton species are predicted to be adversely affected by global warming. It has been found that calcium carbonate, which is the building block of the shell of crustaceans, becomes more soluble due to decreasing temperatures and increasing pressure in the depths of the oceans, which may cause the extinction of certain species. Moreover, it 
has been found that algae blooms have negative effects such as hypoxia caused by low dissolved- oxygen levels and anoxia caused by extremely low or close-to-zero dissolvedoxygen levels. Through the literature, it was determined that hurricane floods would rise, and they would reach about $0.3 \mathrm{~m}$ in $2030 \mathrm{~s}$ and $0.8 \mathrm{~m}$ in $2080 \mathrm{~s}$.

In studies on students at different educational levels carried out by BoyesStanisstreet (1993), Liarakou, Athanasiadis and Gavrilakis (2011), Demirbaş and Pektaş (2009), Ayvacı and Çoruhlu (2009), Bahar and Aydın (2002), Çelikler and Aksan (2011), and Bozkurt and Aydoğdu (2004), it has been stated that the students do not have sufficient knowledge of the threat of global warming and therefore do not bear the necessary concern about the dimensions of the danger (Kaya, 2013). However, in this proposed study, it was found that the global social responsibility levels perceived by the medical students were generally above the average in all three universities. The students' sensitivities were found to be particularly high in the following subjects, and these findings were contributed to the literature: "Recycling of solid wastes," "human beings have to be sensitive to the environment they live in," "nothing about environmental protection is over yet - there is a lot to be done," "there is discomfort about environmental pollution in the world" and "the people who pollute the world must respect the rights of other people of the world."

It is seen as another significant outcome of this study that it revealed differences in the medical school students' levels of knowledge on global warming social responsibility according to their universities. The differences about environmental pollution tended to be positive. This has been interpreted as that the proportion of those who had previously received training in this area was higher.

Moreover, it was found that the vast majority of the students $-76.57 \%$ of them had not received any training on global warming until the time of the study. And, it was also found that the students receiving training had higher levels of awareness of global warming social responsibility. All these have shown that our research was on target for being conducted on medical school students. In this context, we think that it will be suitable to add courses on environment to the curriculum in order to raise medical students' sensitivity to and awareness of the environment.

In this study, it was aimed to reach 500 students, but the research could be done with a sample of 431 people. The research is limited only to students studying in the medical department. In order to generalize the research results and to test the validity of the established intermediary model in sample groups with different characteristics, studies should be conducted with larger samples with students from different departments.

It is obvious that the adversities that will emerge due to global warming will negatively impact the lives of all living things. It is recommended to increase the level of "global social responsibility awareness" in terms of taking measures to stop the progress in this direction, protecting the habitats of living things on earth and ensuring the continuity of life.

\section{References}

Akın, G., (2006). Causes and consequences of global warming. AU Journal of the Faculty of Language and History, 46(2) 29-43.

Anthes, R. A, Corell R. W., Holland, G., \& Hurrel J. W., (2008). Hurricanes and global warming-Potential link ages and consequences, Bulletin of the American Meteorological Society. 85(5) 623-628. 
Barnet T. P, Adam J. C, Lettenmaier D. P., (2005) Potential impacts of a warming climate on water availability in Snow-dominated regions. International Journal of Science Nature, (438) 303-309.

Başer, E. H., \& Kılınç E (2015) Global social responsibility scale: Validity and reliability study. Sakarya University Journal of Education, 5(3), 75-89.

Bennett, L., (2017) Algae, cyanobacteria blooms and climate change. A Publication of the Climate Institute, 1-13.

Blum, H. L. (1985). Health sector trends around the world. Möbius: A Journal for Continuing Education Professionals in Health Sciences, 5(3), 59-83.

Breivik, Ø., Mogensen, K., Bidlot, J. R., Balmaseda, M. A., \& Janssen, P. A. (2015). Surface wave effects in the NEMO ocean model: Forced and coupled experiments. Journal of Geophysical Research: Oceans, 120(4), 2973-2992.

Cavaleri, L., Fox-Kemper, B., \& Hemer, M. (2012). Wind waves in the coupled climate system. Bulletin of the American Meteorological Society, 93(11), 1651-1661.

Coşkun, R, Altunışık R, \& Yıldırım E (2017). Research methods in social sciences applied spss. Sakarya: Sakarya Publishing

Çepel, N., (2008). Ecological problems and solutions. Ankara: Tübitak Popular Science Books.

Doney, S. C., (2006) The dangers of ocean acidification. Scientific American. 294(3) 5865.

Fan, Y., \& Griffies, S. M. (2014). Impacts of parameterized Langmuir turbulence and nonbreaking wave mixing in global climate simulations. Journal of Climate, 27(12), 4752-4775.

Hemer, M. A., Wang, X. L., Weisse, R., \& Swail, V. R. (2012). Advancing wind-waves climate science: The COWCLIP project. Bulletin of the American Meteorological Society, 93(6), 791-796.

Karim, M. F., \& Mimura, N. (2008). Impacts of climate change and sea-level rise on cyclonic storm surge floods in Bangladesh. Global environmental change, 18(3), 490-500.

Kaya, M. F., (2013). Metaphor perceptions of social studies teacher candidates for the concept of "Global Warming Sosyal. Eastern Journal of Geography. 18(29) 117134.

Li, Q., Webb, A., Fox-Kemper, B., Craig, A., Danabasoglu, G., Large, W. G., \& Vertenstein, M. (2016). Langmuir mixing effects on global climate: WAVEWATCH III in CESM. Ocean Modelling, 103, 145-160.

McCarthy, J. J, Canziani, O. F, Leary, N. A, Dokken, D. J, \& White, K. S (2001) Climate change 2001: Impacts, adaptation, and vulnerability. UK: IPCC Cambridge University Press.

Mousavi M. E, Irish J. L, Frey A.E, Edge B. L (2011) Global warming and hurricanes: the potential impact of hurricane intensification and sea level rise on coastal flooding. Climate Change, 104(3-4) 575-597.

Nakano, S. I., Yahara, T., \& Nakashizuka, T. (Eds.). (2016). Aquatic Biodiversity Conservation and Ecosystem Services. Springer Singapore.

Nart. N., (2009) Global warming, before it's too late. Istanbul: IM Publishing.

O'Neil J. M, Davis T. W, Burford M. A, \& Gobler C. J (2012) The rise of harmful cyanobacteria blooms: The potential roles of eutrophication and climate change. Harmful Algae, 1, 313-334. 
Orbay, K., Cansaran, A., \& Kalkan, M., (2009). The perspectives of pre-service teachers to global warming. Ahmet Keleşoğlu Journal of Education Faculty, 27, 85-97.

Orr, J. C, Fabry V. J, Aumont, O, Bopp L, Doney S. C, Feely R. A, Gnanadesikan A, Gruber N, Ishida A, Joos F, \& Key R. M (2005). Anthropogenic ocean acidification over the twenty-first century and its impact on calcifying organisms. Nature, 437(29) 681-687.

ÖSYM, Turkey. (2013). 2012-2013 success in the medical department and base scores, https://www.genctercih.com/2014-tercihleri-icin-2012-2013-karsilastirmali-

bolum-taban-puanlar-kontenjan-basari- siralari/tip(TIP)-bolumleri-icin-20122013-basari-sirasi-taban-puan-karsilastirmasi-devlet-ozel-vakif.pdf, (Accessed 15 June 2018)

ÖSYM, Turkey (2012) Number of exam application by years, https://www.unikampus.net/yillara-gore-universite-sinav-lgs-lys-yks-basvurusayilari, (Accessed 15 June 2018)

Öztürk, K., (2002 Global climate change and its potential impact on Turkey, Gazi University Education Faculty Journal, 1 47-65.

Sabine, C. L, Feely, R. A, Gruber N, Key, R. M, Lee, K, Bullister J. L, Wanninkhof R, Wong, C. S, Wallace D. W. R, Tilbrook, B. (2004) The oceanic sink for anthropogenic $\mathrm{C} \mathrm{O}_{2}$. Science, 305(5682) 367-371.

Schreiner, C, Henriksen E. K, \& Hansen, P. J. K (2005) Climate education: Empowering today's youth to meet tomorrow's challenges. Studies in Science Education, 41(1) 3-50.

Schultz, R, Johnson, A. C., (1976) Management of hospitals. New York: McGraw Hill Book Company.

Spence, C. (2007). Global warming (Translate: Gönen S, A ğar S). İstanbul: Pegasus Publishing.

Smith T. J, Anderson G. H, Balentine K, Ginger T, Greg A. W, Whelan K. R. T., (2009) Cumulative impacts of hurricanes on Florida mangrove ecosystems: Sediment deposition. Storm Surges and Vegetation. 29(1) 24-34.

Uzmen, R., (2007). Global warming and climate change. Istanbul: Bilge Publishing. 